Check for updates

Global Health Centre at the Graduate Institute of International and Development Studies, Geneva, Switzerland

Correspondence to: I Kickbusch kickbusch@bluewin.ch Cite this as: BMJ2021;372:n527 http://dx.doi.org/10.1136/bmi.n527

Published: 25 February 2021

\section{The case for an international pandemic treaty}

\author{
A treaty would protect lives, livelihoods, security, and human rights \\ Haik Nikogosian, Ilona Kickbusch
}

There is longstanding reluctance to use the treaty powers of the World Health Organization. They have been used only once-for the adoption of the WHO Framework Convention on Tobacco Control in 2003. ${ }^{1}$ Now the president of the European Council has called for an international treaty on pandemics, ${ }^{2}$ a proposal later supported by the director general of WHO.

Others have made similar calls. ${ }^{3}$ In January 2021, an independent panel stated that the WHO's existing pandemic alert system "is not fit for purpose" and that "a new global framework is needed to support prevention of and protection from pandemics." ${ }^{4}$ In parallel, a review committee ${ }^{5}$ noted several deficiencies in the current legal framework governing international spread of disease (the International Health Regulations ${ }^{6}$ ), including the lack of a standalone mechanism for monitoring and evaluation of compliance. In a more forthright statement, the Global Preparedness Monitoring Board called for a United Nations summit to agree on an international framework for health emergency preparedness and response. ${ }^{7}$

The debate around whether-and where-an international pandemic treaty or other strong international framework should be negotiated is likely to take centre stage globally in the coming months. In our view, any decision to negotiate a global health treaty should meet three criteria: the problem should be of a global concern and growing magnitude; transnational factors must play a dominant role; and existing instruments must be inadequate. ${ }^{8}$ Pandemics meet the first two criteria, and probably the third given ongoing debate about the adequacy of the International Health Regulations during covid-19. In principle, a new treaty could be negotiated under the auspices of WHO, the UN, or both.

A process led by WHO is likely be the most straightforward option, although concerns may arise over WHO's ability to cover important areas such as finance, trade, supplies, law enforcement, and the broader economic and social disruptions caused by a pandemic. In response to covid-19, global compliance has been weakest with regulations relating to non-health sectors such as transport, ports, and borders.

A treaty led by the UN might be more effective on critical intersectoral issues, but important work on technical details could be challenging in the highly political UN environment in New York. A framework convention approach, which leaves some of the detail to later protocols and guidelines, would be an easier path but only if countries could agree on short definite timelines for negotiating such instruments. Another approach could be to draft and provisionally negotiate articles requiring specialised expertise in Geneva before final negotiations in New York; several health issues were brought to the UN General Assembly through a similar path in recent years.

\section{Following precedent}

One immediate precedent is the WHO's Framework Convention on Tobacco Control (FCTC), which opened a new legal dimension in international health cooperation. It has become one of the most widely and rapidly embraced treaties in the history of the UN-a sign of the broad appeal of a new type of multilateral regime in health.

The FCTC turned several challenging public health functions into legally binding obligations-a national coordination mechanism, a uniform reporting system, transfer of knowledge and technology internationally, and protection from industry interests. ${ }^{9}$ It also showed the feasibility of working with non-health sectors within an international legal system, the feasibility of negotiating further protocols and guidelines promptly, and the power to safeguard the interests of health in the face of conflicting agendas and legal disputes. These lessons would help inform new legal frameworks in the health arena, and in pandemics in particular. Tobacco use is, after all, a type of pandemic.

The UN system more broadly has other valuable features, including cross sectoral working on very large scale challenges (eg, the UN Framework Convention on Climate Change $)^{10}$; legal provisions that are highly relevant to pandemics, such as the Nagoya Protocol on use of genetic resources ${ }^{11}$; joint treaty administration by existing UN system bodies (eg, the Protocol on Water and Health) ${ }^{12}$; a human rights based approach ${ }^{13}$ (UN human rights treaties); and other important treaty practices such as finance mechanisms (eg, the Global Environmental Facility ${ }^{15}$ for environmental conventions) and monitoring compliance (eg, the International Narcotics Control Board $^{16}$ for drug control conventions).

Finally, a broader UN framework on pandemics could be considered. The Sendai Framework for Disaster Risk Reduction, ${ }^{14}$ for example, has features potentially useful for an international instrument governing pandemics. These include a focus on risk management, responsibilities across sectors and stakeholders, protection of livelihoods along with protection of lives and health, use of UN interagency mechanisms, and global targets to measure progress. However, such frameworks are not a legally binding instrument (although they could eventually lead to one).

The instrument chosen will ultimately depend on the political ambition of individual countries. Given the 
magnitude, scope, and scale of global disruption caused by pandemics, a strong, bold, and above all rapid instrument is now required. It must cover disruptions both in and beyond health, bind all relevant sectors, engage international actors, activate financial mechanisms, define signatories' obligations (and breaches), and agree mechanisms to evaluate compliance. It would also would require ratification by parliaments and trigger subsequent national laws.

A pandemic treaty under the joint auspices of WHO and the UN seems the most viable way forward given the urgency and the implications of the current pandemic beyond health to livelihoods, economies, security, solidarity, and human rights. If a treaty is deemed not immediately feasible, a UN framework with built-in power and mandate to negotiate a treaty could be the road to take.

Competing interests: We have read and understood BMJ policy on declaration of interests and declare the following interests: $\mathrm{HN}$ is former head of the secretariat of the WHO Framework Convention on Tobacco Control. IK is a member of the Global Preparedness Monitoring Board.

Provenance and peer review: Commissioned; not externally peer reviewed.

1 WHO Framework Convention on Tobacco Control. https://apps.who.int/iris/bitstream/handle/10665/42811/9241591013.pdf;jsessionid=CC87823473E52B597422F88E9370968B?sequence $=1$

2 European Council. President Charles Michel on an international treaty on pandemics. Press release, 3 Dec 2020. https://www.consilium.europa.eu/en/press/press-releases/2020/12/03/pressrelease-by-president-charles-michel-on-an-international-treaty-on-pandemics/.

3 Pandemic Mitigation Project. https://pandemicmitigationproject.com/

4 Independent Panel for Pandemic Preparedness and Response. Second report on progress. 2021. https://live-the-independent-panel.pantheonsite.io/wp-content/uploads/2021/01/IndependentPanel_Second-Report-on-Progress_Final-15-Jan-2021.pdf

5 WHO. Interim progress report of the review committee on the functioning of the International Health Regulations (2005) during the covid-19 response. 2021. https://apps.who.int/gb/ebwha/pdf_files/EB148/B148_19-en.pdf.

6 WHO. International Health Regulations (2005). 3rd ed. 2016. https://www.who.int/publications/i/item/9789241580496

7 Global Preparedness Monitoring Board. A world in disorder. 2020. https://apps.who.int/gpmb/assets/annual_report/GPMB_AR_2020_EN.pdf.

8 Kickusch I, Nikogosian H, Kazatchkine M, Kokeny M. A guide to global health diplomacy. Graduate Institute of International and Development Studies, 2021, https://www.graduateinstitute.ch/sites/internet/files/2021-02/GHC-Guide.pdf.

9 Nikogosian H, Kickbusch I. The legal strength of international health instruments-what it brings to global health governance? Int J Health Policy Manag 2016;5:683-5. doi: 10.15171/ijhpm.2016.122. pmid: 28005547

10 United Nations Framework Convention on Climate Change. https://unfccc.int/process-andmeetings/the-convention/what-is-the-united-nations-framework-convention-on-climate-change

11 Convention on Biological Diversity. Nagoya protocol on access to genetic resources and the fair and equitable sharing of benefits arising from their utilization to the convention on biological diversity. 2014. https://www.cbd.int/abs/

12 UN Economic Commission for Europe. Protocol on water and health to the 1992 convention on the protection and use of transboundary watercourses and international lakes. https://unece.org/environment-policy/water/protocol-on-water-and-health/about-the-protocol/introduction

13 UNHCR. International covenant on economic, social and cultural rights. https://www.ohchr.org/EN/Professionallnterest/Pages/CESCR.aspx

14 UNDRR. Sendai framework for disaster risk reduction 2015-2030. https://www.undrr.org/publication/sendai-framework-disaster-risk-reduction-2015-2030

15 UN Environment Programme. Global financing facility. https://www.unep.org/about-un-environment/funding-and-partnerships/global-environment-facility

16 International Narcotics Control Board. https://www.incb.org/

This article is made freely available for use in accordance with BMJ's website terms and conditions for the duration of the covid-19 pandemic or until otherwise determined by BMJ. You may use, download and print the article for any lawful, non-commercial purpose (including text and data mining) provided that all copyright notices and trade marks are retained. 